\title{
Analysing the Effects of Critique Techniques on the Success of Interior Architecture Students
}

\author{
Ciler Gozde Gunday Gul and Yasemin Afacan
}

\begin{abstract}
In architectural design education, the most significant part in the curriculum is the design studio, where students learn how to design. Critique has a crucial role in the design studio, and in determining the best and most beneficial critique type for the architectural design education process. Student attitudes toward critiques and student satisfaction level with each critique technique are also significant. To that end, this article explores design studio learning by reviewing the design learning process and types of design critiques. Focusing on three critique techniques used in design education (desk critiques, pin-up critiques and group critiques), the article analyses correlations between student attitudes toward each technique and its contribution to the design process. Research was conducted with 84 third-year interior architecture students from the 2014-15 Fall semester at a university. No statistically significant differences were found between group and pin-up critiques in terms of students' preferences and their final performance scores; however, there was a statistically significant relationship between student preferences toward desk critiques and student success. Furthermore, the contribution of a critique technique to the design process was found to be highly correlated with student preference for this technique.
\end{abstract}

\section{KEYWORDS}

Architectural design education, design studios, critique techniques, desk critique, pin-up critique, group critique

Architectural design education, which consists of studio teaching and project designing, is a matter of synthesising, evaluating and presenting ideas for solutions to common design problems (Afacan 2012). Architectural design education is also a context that emphasises oral communication proficiency (Dannels 2005). According to Anthony (1991), oral communication assignments are the primary method of evaluation in design studios. Oral communication as critique also has an important role in architectural design education, especially in design studios in terms of student performance. In architectural design education, the most significant part in the curriculum is the design studio, where students learn how to design. In the studio, students develop and gain knowledge of design thinking, which plays a crucial role in architectural design education (Kim et al. 2015). Students are also expected to use their knowledge from different disciplines to create design projects (Nicol \& Pilling 2005). Each student's way of understanding critiques, attitude toward different critique techniques, what the student has experienced from the critiques and how different critique techniques affect his or her success, become key questions for design studios. Although there are a number of studies in the design literature on the conceptualisation, articulation, implementation and integration of design critiques (Fischer et al. 2001; Oh 2010; Oh et al. 2013; Salama 1995; Schön, 1983, 1985), a student- 
centred perspective is missing. How critique types influence student attitudes, experiences and successes is rarely explored. Conveying the required information, guiding throughout the design learning process and establishing the most satisfactory interaction between students and instructors via critiques is a challenging task in design studios. The tendency to only give feedback could lead to disconnection between students and faculty. Misunderstandings of given critiques because of possible student dissatisfaction with the delivery could lead to frustration and result in low performance scores in studio. Thus, this article explores design studio learning by reviewing the design learning process and design critiquing. Focusing on three critique techniques used in the design studio (desk critiques, pin-up critiques and group critiques), the article analyses correlations between student attitudes toward each critique technique and its contribution to the design process.

\section{The learning process in the design studio}

How the learning process is defined in the design studio becomes significant in understanding the key role of critiquing as an essential pedagogical tool. The 'design studio is characterized by a teaching model that is distinctly suited for problem-solving' (Maturana 2014). According to Ledewitz (1985), there are three aspects of design education in terms of teaching: (1) learning and practice, (2) learning a new language and (3) learning how to think architecturally. Firstly, in design studios students learn and practise a number of new skills. Secondly, students learn the new language of design. Thirdly, Ledewitz $(1985,2)$ maintains that 'in the design studio, students learn "thinking architecturally"' referring to a 'particular domain of problems and solutions that characterize, and are fundamental to professional performance'. The learning process in the design studio involves not only teaching all three aspects but also learning them at the same time (Ledewitz 1985). Demirbaş \& Demirkan (2003) note that organising essential knowledge and representing this knowledge are also significant components of design studios. Sagun (2003) claims that the process in the design studio occurs through identifying a design brief and introducing the design problem as well as introducing the qualifications of the problem set. At that point, students explore the current problem through discussions. The expectations are clearly drawn, and throughout the semester students and instructors come together through informal and formal meetings (Sagun 2003).

In the literature, there is more than one description of the learning process. Schunk (1996) provides three criteria that help to define a learning model. The first criterion is that one can learn when one becomes able to perform something differently. According to this thinking, 'learning is based on what people say, write and do' (Schunk 1996, 4). The second criterion maintains that although something may be learned, it may not be remembered due to factors like fatigue or alcohol (Schunk 1996). The third criterion is about learning by doing. Schunk (1996) states that learning can occur through practice, observation and experiences. As a learning process, critiquing helps students identify their weak and strong points, which they may not be able to do on their own (Motley 2015). Thus, design critiquing has always been an integral part of design education. As such, students firstly should understand the critique, and secondly, the critique should convey a message through the knowledge of the studio master (Uluoğlu 2000). There are also other factors that can affect design critiquing (Oh et al. 2013), which are discussed in detail in the next subsection.

\section{What is a design critique?}

According to Silverman (1992), a critique is an action that identifies problems and user-based solutions through judgments. Ostermann (1998) explains design critique as advice, suggestions and 
questions regarding a project. Fischer et al. (1998) define a critique as a dialogue that enhances knowledge regarding design situations. According to them, the process of critiquing involves supporting design-problem identification and solving. Critiquing also helps access related issues in the information space through emphasising problematical situations and improving arguments related to design solutions (Fischer et al. 1998). Schön (1985) describes design knowledge conveyed during a design critique session using the concept of 'repertoire', which is a collection of descriptions, thoughts, actions and illustrations. He conceptualises the design critique as reflective and communicative coactions with the material and object of a design situation.

To understand the concept of reflection in action, it is important to understand how reflection occurs. Reflection plays a significant part in learning from experiences and allows students to figure out the relationship between theory and practice (Gray 2001). According to Schön (1985), during the critique process there are two ways of interaction: (1) telling and listening and (2) representing and imitating. In telling and listening, the significant point is to highlight the essential concepts for the student (Demirbaş 2001). Also according to Demirbaş, work in the design studio and work out of the studio is similar, which means that students who have difficulty with something in life or society may have difficulty with similar concepts in the studio. However, in the studio students may be able to learn how to conquer their difficulties.

\section{Techniques of the critique session}

'Critique' is defined as the setting that the instructor uses to communicate with students (Oh 2010; Oh et al. 2013), and the design literature shows that there are several critiquing techniques. Oh et al. (2013) review the practice of design critiquing, identify 11 fundamental factors and divide them into two categories: methods and conditions. According to Oh et al. (2013), critiquing methods are composed of five factors: setting, teacher-student relationship, communication modalities, delivery types and delivery methods. The critiquing conditions category has six factors: design phases, individual differences, knowledge/experiences, student response types, design artefacts and learning goals. This article deals with the first category, methods, and focuses on the critique setting, which is how the instructor interacts with the students. A setting is defined according to the number of students, its private-public level, and whether it is formal or informal. Bailey (2004) provides a comprehensive list of critique settings, such as desk critiques, group critiques, interim reviews (pin-up critiques), final reviews and informal interactions. For this article, three settings are of importance (desk, interim or pin-up and group), as these are the most used in the related design education context. A brief description of these three techniques is given in the following subsection.

\section{Desk critique}

'Desk critiques take place throughout the entire semester (typically 12-16 weeks) of a studio course' (Oh 2010, 58). This type of critique provides students with an understanding of the process from the instructor's perspective (Oh et al. 2013). However, based on the relationship between student and instructor, students have different abilities to benefit from a critique and develop it as feedback. Schön (1985) considers the desk critique a significant element of studio teaching, and Koch et al. (2002) find it the most effective critique technique in the design studio, as instructors can observe student progress in detail. According to Dannels (2005), desk critiques are the most informal of the oral genre in design studios, and instructors spend significant one-on-one time with each student in this setting. 


\section{Pin-up critique}

Pin-up or interim critiques allow students to develop their projects (Oh et al. 2013). According to Dannels (2005), pin-up critiques are oral representations of a project, where students display their tools on a wall and receive comments from the instructor. In some cases, pin-ups may be more public, where students receive feedback from their instructor and their peers (Oh 2010). In pin-up critiques, students explain what they have done and instructors share their ideas about what they see and perceive (Dannels 2005). Pin-up juries are less informal than final juries; feedback, rather than evaluation, is the goal. For this reason, the comments are more constructive (Anthony 1991; Bailey 2004).

\section{Group critique}

In a group critique instructors and students discuss the presented works of each student while gathered around a desk (Oh et al. 2013). In this method, each student is able to listen to and observe the development process of other students. Farivarsadri (2001) claims that group critiques are most beneficial at the beginning of the design semester at the initiation of design projects, when students are determining possible design solutions to the assigned project. Through group critiques, students can see each other's possible solutions, which may give them ideas for their own solutions. Since the group critique is an informal setting, students who lack confidence in public speaking may feel more comfortable actively participating in this type of critique. Sagun (2003) also emphasises that students can develop their design ideas through group critiques by actively commenting on other project solutions.

\section{Methodology}

\section{Sample group}

To analyse the effects of different critique techniques on student attitudes, experiences and successes, 84 third-year Interior Architecture and Environmental Design students at a university were chosen from the 2014-15 Fall semester. The author selected third-year students for three reasons: (1) due to the complexity of the projects, the third-year design studio requires different critique techniques; (2) third-year students begin to transform their knowledge gained from other courses and initiate solving spatial problems in more detail; and (3) third-year students are more familiar with different critique techniques than first-year and second-year students.

\section{Procedure}

A four-part survey was given to the sample group. In the first part, the author collected data related to student demographics, such as gender, as well as previous semester design grades and GPAs. Students also chose one of six categories with definitions (Kent 2001) that they most identified with during the critique in the design studio: thinkers, listeners, misunderstanders, sceptics, followers or affirmers. Thinkers reflect what they hear from the instructor and try to combine their ideas and instructor feedback in their design. Listeners understand the instructor feedback but they cannot come up with an applied design. Sceptics are unconvinced regarding instructor ideas and have a tendency to discount the feedback they receive. Misunderstanders deliberately misinterpret instructor comments and only apply what they want to hear. Followers remember and apply instructor critiques concretely. Finally, affirmers assume that the instructor has the same idea as they do (Kent 2001). 
In the second part of the survey, student attitudes toward different critique techniques were explored through a 5-point Likert scale (5 for 'Strongly Agree' and 1 for 'Strongly Disagree') for 25 statements. Of these, 8 statements were about the group critique, 9 related to the pin-up critique, and 8 related to the desk critique. In the third part, a 5-point Likert scale (5 for 'Very Satisfied' and 1 for 'Very Dissatisfied') was used with 21 statements (7 for each critique technique) and concentrated on student satisfaction with each critique technique. The last part of the survey included open-ended questions, where students shared their ideas and comments regarding each technique and some suggestions for doing things differently. According to Cronbach's Alpha, the reliability of the survey is 0.926 .

\section{Analysis and discussion}

The results of the survey were analysed both quantitatively and qualitatively. The quantitative analysis was done with the Statistical Package for the Social Sciences 20 (SPSS). Statistical calculations, descriptive statistics, chi-square, t-test and correlation matrices were used. The statistical data is discussed in three parts. In the first part, descriptive statistics involve descriptive tables according to the number of participants, gender, design grades and GPAs. Student responses to the satisfaction degrees were analysed through descriptive analyses. To determine student categorisations and their relation to student' success, a t-test was also conducted in this part. In the second part, correlation analysis was used to identify correlations between critique techniques and student attitudes toward them. Correlation matrices were calculated to identify associations between attitude items. The relationships between items are stated in terms of correlation coefficients, that is, between 0.9 and 1.0 indicates a very high correlation between two variables, whereas between 0.5 and 0.7 indicates a moderate correlation and between 0.3 and 0.5 indicates a low correlation (Argyrous 2005). In the third part, student experiences and comments are shared in the form of direct quotations.

\section{Descriptive analysis}

Sixty-eight female students and 16 male students completed the survey. The mean of their previous semester design grades is 80, a fitted ' $\mathrm{B}$ ' in a letter grade. The mean of the 2014-15 Fall semester final design jury grades is 77 , a fitted ' $\mathrm{B}$ '' in the letter system. According to the student categorisation results, there were 21 thinkers, 10 listeners, 13 sceptics, 27 misunderstanders, 10 followers and 3 affirmers in the sample group (see Table 1).

In addition to the descriptive analyses, ANOVA was also conducted to determine whether student categorisation has any influence on student final grades and GPA (Table 2). The results show that

Table 1. Descriptive analyses of student categorisation and previous semester final grades

\begin{tabular}{lccc}
\hline & $N$ & Mean & Std. Deviation \\
\hline Thinkers & 21 & 1.95 & 0.384 \\
Listeners & 10 & 1.80 & 0.422 \\
Sceptics & 13 & 2.15 & 0.555 \\
Misunderstanders & 27 & 2.04 & 0.437 \\
Followers & 10 & 2.00 & 0.471 \\
Affirmers & 3 & 1.67 & 0.577 \\
Total & 84 & 1.99 & 0.451 \\
\hline
\end{tabular}


Table 2. Analyses of variance between final grades and student categorisation

\begin{tabular}{lcclll}
\hline & Sum of Squares & $d f$ & Mean Square & $F$ & Sig. \\
\hline Between groups & 8.103 & 5 & 1.621 & 4.005 & 0.003 \\
Within groups & 31.564 & 78 & 0.405 & & \\
Total & 39.667 & 83 & & & \\
\hline
\end{tabular}

there is a statistical difference among student categorisation types and their final grades $(F(5.78)=$ 4.005, df: 5, p: 0.003, $\left.\mathrm{N}^{2}: 0,245\right)$.

\section{Student attitudes and success toward critique techniques}

Student responses to the 25 attitude statements were also analysed. According to the highest mean, students feel comfortable asking questions in desk critiques (Mean=4.45). The lowest statement mean shows that students prefer group critiques rather than desk critiques (Mean=2.48). To determine whether gender affects the results, the mean values of the three critique statements were also calculated separately. When gender is considered, Statement 17, 'I understand the given feedbacks in desk critiques', has the higher mean value (Mean=4.43), whereas Statement 6, 'the way that group critique is delivered', has the lowest mean value for females (Mean=3.17). Males have the highest mean (Mean=4.44) for Statement 16, 'learning experience and gaining knowledge in desk critiques' and the lowest mean (Mean= 3.06) for Statement 3, 'learning experience in group critiques' and 'available amount of time allocated for group critiques'.

According to student responses to the 21 satisfaction statements, Statement 17, 'I understand the given feedbacks in desk critiques', has the highest mean (Mean=4.43). The lowest mean is for Statement 6, 'how group critiques are delivered' (Mean=3.17). Student GPAs and their preferences in terms of critique techniques are also analysed in relation to the highest and the lowest mean value distribution. Statement 19, 'I feel comfortable asking questions in desk critiques', has a higher mean in the attitude statements (Mean=4.45). The most successful students in the class range between a 2.00 and 3.00 GPA and highly disagree with this statement (Table 3).

To determine whether there is a statistically significant relationship between student attitudes about different critique techniques and their GPAs, cross tabulations and chi square tests were conducted. Students whose final grades were A and A- mostly agreed with Statement 23: 'I prefer desk critiques rather than pin-up critiques.' The chi-square test was conducted to examine whether there is any statistically significant relationship between student preferences of group critiques and pinup critiques. It was found that there is no statistically significant relationship in terms of student preferences between the group and pin-up critiques $\left(X^{2}(20, N=84)=12.99, p=0.59\right)$ and between

Table 3. Cross tabulation between GPA ranges and highest mean attitude statement

\begin{tabular}{llllrrr}
\hline Feeling comfortable asking questions in desk critiques & & & \\
\hline GPA Range & Strongly disagree & Disagree & Neither agree nor disagree & Agree & Strongly agree & Total \\
\hline $\mathbf{1 . 8 0} \leq \boldsymbol{x} \leq \mathbf{1 . 9 9}$ & 0 & 0 & 0 & 1 & 0 & 1 \\
$\mathbf{2 . 0 0} \leq \boldsymbol{x} \leq \mathbf{2 . 9 9}$ & 2 & 0 & 7 & 14 & 37 & 60 \\
$\mathbf{3 . 0 0} \leq \boldsymbol{x} \leq \mathbf{3 . 4 9}$ & 0 & 2 & 1 & 1 & 14 & 18 \\
$\mathbf{3 . 5 0} \leq \boldsymbol{x} \leq \mathbf{4 . 0 0}$ & 0 & 0 & 0 & 0 & 5 & 5 \\
Total & 2 & 2 & 8 & 16 & 56 & 84 \\
\hline
\end{tabular}


the pin-up and desk critiques $\left(\mathrm{X}^{2}(20, \mathrm{~N}=84)=10.41, \mathrm{p}=0.86\right)$, whereas there is a highly statistically significant relationship between the desk and group critiques $\left(X^{2}(20, N=84)=33.63, p=0.006\right)$.

\section{Correlations of students' attitudes and preferences for critique techniques}

Table 4 summarises the correlation matrix with standard deviations for all factor components (Pearson correlation coefficients, $n=84$ ). All correlation coefficients that were significant at a 95 per cent confidence level showed positive correlations. According to the results of the correlation matrix, the highest correlation occurs between the following statements about desk critiques: 'Desk critiques are better for the design process' (Statement 21) and 'I prefer desk critiques rather than pin-up critiques' (Statement 23) (0.919). The second largest correlation occurs between the statements of 'I learn more in desk critiques' (Statement 18) and 'I prefer desk critiques rather than group critiques' (Statement 22) (0.829). 'I learn more in desk critiques' is also highly correlated with 'I prefer desk critiques rather than pin-up critiques' (0.811). 'Desk critiques are useful when the same instructor gives the critique each time' (Statement 19) is highly correlated with 'I prefer desk critiques rather than pin-up critiques' (Statement 23) (0.803). There is also a high correlation between the following statements: 'Desk critiques are better for the design process' (Statement 21) and 'I prefer desk critiques rather than pin-up critiques' (Statement 23) (0.784). Briefly, it can be said that there is almost a perfect association between 'Desk critiques are better for the design process' (Statement 21) and 'I prefer desk critiques rather than group critiques' (Statement 22) (0.919). There is a moderate

Table 4. Correlation matrix of students' attitudes toward desk critiques (Pearson correlation coefficients, $n=84$ )

\begin{tabular}{|c|c|c|c|c|c|c|c|c|}
\hline Spearman's rho & $\begin{array}{l}\text { I have a } \\
\text { positive } \\
\text { attitude } \\
\text { toward } \\
\text { desk } \\
\text { critiques }\end{array}$ & $\begin{array}{l}\text { Desk } \\
\text { critiques } \\
\text { are useful } \\
\text { when the } \\
\text { same } \\
\text { instructor } \\
\text { gives the } \\
\text { critique } \\
\text { each time }\end{array}$ & $\begin{array}{l}\text { I learn } \\
\text { more in } \\
\text { desk } \\
\text { critiques }\end{array}$ & $\begin{array}{l}\text { I feel } \\
\text { comfortable } \\
\text { asking } \\
\text { questions in } \\
\text { desk critiques }\end{array}$ & $\begin{array}{l}\text { Students } \\
\text { in desk } \\
\text { critiques } \\
\text { ask more } \\
\text { questions }\end{array}$ & $\begin{array}{l}\text { Desk } \\
\text { critiques } \\
\text { are better } \\
\text { for the } \\
\text { design } \\
\text { process }\end{array}$ & $\begin{array}{l}\text { I prefer } \\
\text { desk } \\
\text { critiques } \\
\text { rather } \\
\text { than } \\
\text { group } \\
\text { critiques }\end{array}$ & $\begin{array}{l}\text { I prefer } \\
\text { desk } \\
\text { critiques } \\
\text { rather } \\
\text { than } \\
\text { pin-up } \\
\text { critiques }\end{array}$ \\
\hline $\begin{array}{l}\text { I have a positive attitude } \\
\text { toward desk critiques }\end{array}$ & 1.000 & & & & & & & \\
\hline $\begin{array}{l}\text { Desk critiques are useful } \\
\text { when same instructor } \\
\text { gives the critique each time }\end{array}$ & $0.571^{* *}$ & 1.000 & & & & & & \\
\hline I learn more in desk critiques & $0.668^{* *}$ & $0.737^{* *}$ & 1.000 & & & & & \\
\hline $\begin{array}{l}\text { I feel comfortable asking } \\
\text { questions in desk critiques }\end{array}$ & $0.589^{* *}$ & $0.621^{* *}$ & $0.722^{* *}$ & 1.000 & & & & \\
\hline $\begin{array}{l}\text { Students in desk critiques } \\
\text { ask more questions }\end{array}$ & $0.530^{* *}$ & $0.648^{* *}$ & $0.675^{* *}$ & $0.721^{* *}$ & 1.000 & & & \\
\hline $\begin{array}{l}\text { Desk critiques are better } \\
\text { for the design process }\end{array}$ & $0.596^{* *}$ & $0.760^{* *}$ & $0.798^{* *}$ & $0.783^{* *}$ & $0.744^{* *}$ & 1.000 & & \\
\hline $\begin{array}{l}\text { I prefer desk critiques } \\
\text { rather than group critiques }\end{array}$ & $0.641^{* *}$ & $0.803^{* *}$ & $0.829 * *$ & $0.813^{* *}$ & $0.689 * *$ & $0.919^{* *}$ & 1.000 & \\
\hline $\begin{array}{l}\text { I prefer desk critiques } \\
\text { rather than pin-up critiques }\end{array}$ & $0.610^{* *}$ & $0.684^{* *}$ & $0.811^{* *}$ & $0.738^{* *}$ & $0.585^{* *}$ & $0.784^{* *}$ & $0.816^{* *}$ & 1.000 \\
\hline
\end{tabular}

${ }^{* *}$ Correlation is significant at the 0.01 level (2- tailed). 
association between 'I ask more questions in desk critiques' (Statement 20) and 'I have a positive attitude toward desk critiques' (Statement 16) (0.589).

To analyse whether there is a correlation between a preferred critique technique and its contribution to the design process, another correlation matrix was conducted (Table 5). According to the correlation matrix, the statements 'Desk critiques are better for the design process' (Statement 21) and 'I prefer desk critiques rather than group critiques' (Statement 22) are highly correlated with each other (0.919). This result supports the second hypothesis, that is, student preference of a critique technique and its contribution to the design process are related. 'Group critiques are better for the design process' (Statement 6) and 'I prefer group critiques rather than desk critiques' (Statement 24) are correlated (0.680). 'Pin-up critiques are better for the design process' (Statement 15) and 'I prefer pin-up critiques rather than group critiques' (Statement 25) are also moderately correlated with each other (0.504). Briefly, it can be said that a critique technique's contribution to the design process is highly correlated with student preference for a technique.

\section{Student comments on critique techniques}

This section presents student comments on critique techniques based on direct quotations from the answers to the open-ended questions. These questions asked for further suggestions about each critique technique. The answers were grouped into two categories: the first category emphasises the importance of time, whereas the second category is about the learning process. Most students felt equal time allocation for different critique types would be preferable. Rather than having more time for the desk critique, they would prefer to discuss the peer solutions in the pin-up and

Table 5. Correlation matrix of student' preference and the critique technique's contribution to the design process (Pearson correlation coefficients, $\mathrm{n}=84$ )

\begin{tabular}{|c|c|c|c|c|c|c|c|}
\hline & $\begin{array}{l}\text { I prefer group } \\
\text { critiques } \\
\text { rather than } \\
\text { desk critiques }\end{array}$ & $\begin{array}{l}\text { Group } \\
\text { critiques } \\
\text { are better } \\
\text { for the } \\
\text { design } \\
\text { process }\end{array}$ & $\begin{array}{l}\text { Pin-up } \\
\text { critiques } \\
\text { are better } \\
\text { for the } \\
\text { design } \\
\text { process }\end{array}$ & $\begin{array}{l}\text { I prefer } \\
\text { pin-up } \\
\text { critiques } \\
\text { rather than } \\
\text { group } \\
\text { critiques } \\
\end{array}$ & $\begin{array}{l}\text { I prefer } \\
\text { desk } \\
\text { critiques } \\
\text { rather } \\
\text { than } \\
\text { group } \\
\text { critiques }\end{array}$ & $\begin{array}{l}\text { I prefer } \\
\text { desk } \\
\text { critiques } \\
\text { rather } \\
\text { than pin-up } \\
\text { critique }\end{array}$ & $\begin{array}{l}\text { Desk } \\
\text { critiques } \\
\text { are better } \\
\text { for the } \\
\text { design process }\end{array}$ \\
\hline $\begin{array}{l}\text { I prefer group critiques } \\
\text { rather than desk critiques }\end{array}$ & 1.000 & & & & & & \\
\hline $\begin{array}{l}\text { Group critiques are better } \\
\text { for the design process }\end{array}$ & $0.680^{* *}$ & 1.000 & & & & & \\
\hline $\begin{array}{c}\text { Pin-up critiques are better } \\
\text { for the design process }\end{array}$ & $0.315^{* *}$ & $0.266^{*}$ & 1.000 & & & & \\
\hline $\begin{array}{l}\text { I prefer pin-up critiques } \\
\text { rather than group critiques }\end{array}$ & 0.111 & $0.156^{*}$ & $0.504^{* *}$ & 1.000 & & & \\
\hline $\begin{array}{l}\text { I prefer desk critiques } \\
\text { rather than group critiques }\end{array}$ & $-0.515^{* *}$ & $-0.291^{* *}$ & -0.109 & -0.068 & 1.000 & & \\
\hline $\begin{array}{l}\text { I prefer desk critiques } \\
\text { rather than pin-up critiques }\end{array}$ & $-0.424^{* *}$ & $-0.241 *$ & -0.199 & 0.116 & $0.816^{* *}$ & 1.000 & \\
\hline $\begin{array}{l}\text { Desk critiques are better } \\
\text { for the design process }\end{array}$ & $-0.454^{* *}$ & $-0.240^{*}$ & -0.134 & 0.099 & $0.919^{* *}$ & $0.784^{* *}$ & 1.000 \\
\hline
\end{tabular}

${ }^{* *}$ Correlation is significant at the 0.01 level (2-tailed). *Correlation is significant at the 0.05 level (2-tailed). 
group critiques as much as possible so they could have more opportunity to analyse different design solutions. Some examples from the first category are as follows:

There should be equal and more time for all different kinds of critiques during the process. (Student 7)

At the beginning of each design problem, we find ourselves suddenly inside of the project. We need more time to analyze the design requirements; we need more group critiques and pin-up critiques at the beginning of the semester. (Student 22)

I would like to have time to see similar projects in the design studios. I would also like to see how the instructors might find solutions for the same design problems. This may be an effective way to teach me how to design. (Student 9)

Comments related to the learning process were more about suggestions on the importance of interaction between instructors and peers. Students indicated they would like to have more pin-up critiques, as they found pin-ups very beneficial at all phases of the design process. They felt they could ask more questions and be introduced to more design solutions during the pin-up critique because it involved the entire class. Some of the students also highlighted the importance of seminar-type critiquing and brainstorming in the early stages of designing and sketching.

Interactive critiques such as pin-up and group critiques are much better for inspiring and developing the design process. (Student 3)

If students have the chance for desk critiques in a lesson, the following lesson should be in a group. Group critiques are like brainstorming sessions and more questions and ideas occur but may cause confusion. (Student 14)

To understand the design problem given at the beginning of semester, we need more brainstorming and we should have more research sessions that can be done with instructors. (Student 78)

We need more pin-up critiques to be aware of the process. (Student 12)

\section{Conclusion}

Critiquing is essential for the learning process in the design studio. The results of this study encompass important considerations for the design critiquing practice from the student perspective. The desk critiques and its relationship to the design process prove to be significant for students to achieve learning outcomes and be successful in design studio environments. As Koch et al. (2002) state, desk critiques are the best technique in the design studio through which to follow the student's design process. This study supports the finding that most students prefer desk critiques to group and pin-up critiques. Students usually have desk critiques with the same instructor, which they prefer. However, responses to the open-ended questions revealed that students want to have group critiques at the initial steps of the design process. Farivarsadri (2001) also mentions that 
group critiques are preferable early in the term, such as at the beginning of the design studio, because they help students develop other solutions to the same design problem (Farivarsadri 2001). In addition to critique technique preferences, some students noted that when the instructor drew a sketch on the students' design tools, they remembered the key points of the critiques. This finding is also supported by Oh et al. (2013), that is, the written critique has many advantages for students because it is how they construct stories. Furthermore, according to the results of the current study, having a positive attitude toward critiquing is highly associated with being comfortable, that is, asking more questions.

There are several limitations to the findings. A larger sample would allow for better analyses of the effects of different critique techniques on the success of design students. Furthermore, based on the study design, different learning preferences of students could address different performance and correlation results between student attitudes toward each critique technique. Although this study stated desk critiques as the most preferred critiques, there are also teaching preferences of professors so that desk critiques can vary greatly from one professor to the next. For example, when a studio teacher reviews student designs, the teacher uses knowledge from their ownexperience and scans their repertoire for similar problems (Oh et al. 2013). Thus, the work of design students in a desk critique setting might be more accurately 'the work of the teacher'. The relationships between student and instructor, communication modalities and the instructor response style, facilitative or directive, also have an influence on students' learning (Belluigi 2016). Furthermore, as stated by Oh et al. (2013), avoiding desk critiques and conducting peer review sessions instead is important because the overpowering authority of the instructor could discourage students in desk critiques from participating freely in debate, asking questions and reflecting on their own design. Therefore, for a better examination of results additional research on short-term learning outcomes (immediate results) and long-term retention and adaptability could be studied with different studio teachers.

The results of this study have implications for developing more systematic ways of critiquing to integrate with the diverse requirements of each phase of the design process. Student comments highlight the importance of the pedagogy of critiquing, which means emphasising the critical and fundamental aspects of a better design learning process. The results show that although the desk critique is the most satisfactory critique technique, instructors should not use it solely, but establish their own critiquing strategies by articulating pin-up and group critiques based on the requirements of each design studio problem. As a further study, a longitudinal survey of different design studio years focusing on different stages of the design process could be conducted.

Ciler Gozde Gunday Gul is an interior architect. She received her Master's degree in the Department of Interior Architecture and Environmental Design, Bilkent University, Ankara, Turkey, in 2015. Her research interests include architectural design education and design studies. T.C. Atılım University, Graduate School of Natural and Applied Sciences, Faculty of Architecture, PhD Program, Kızılcasar, Incek 06836 Ankara, Turkey. Email: cilergnday@windowslive.com

Yasemin Afacan is an assistant professor in the Department of Interior Architecture and Environmental Design at Bilkent University, Ankara, Turkey. She holds a PhD in interior architecture obtained from Bilkent University in 2008 and a MA in architecture obtained from Middle East Technical University in 2004. Before joining Bilkent University, she worked as a lecturer in Queens University Belfast, UK. She has published in applied ergonomics, engineering design, knowledge-based systems, and design studies in various refereed 
journals internationally. She teaches design processes and sustainable design for interiors, and her research interest has been focused on inclusive design (processes, tools and methodology), aging studies and architectural design education. Contact address: Bilkent University, Department of Interior Architecture and Environmental Design, 06800 Ankara, Turkey. Email: yasemine@bilkent.edu.tr

\section{References}

Afacan, Y. (2012) Investigating the effects of group working in studying interior architecture, Procedia-Social and Behavioral Sciences, Vol. 51, No. 1, pp. 506-11.

Anthony, K. H. (1991) Design Juries on Trial: The Renaissance of the Design Studio (online). Available at: http://www.worldcat.org/title/design-juries-on-trial-the-renaissance-of-the-designstudio/oclc/551574194?referer=di\&ht=edition (accessed 15 May 2015)

Argyrous, G. (2005) Statistics for Research, 2nd edn. London: Sage.

Bailey, R. (2004) The digital design coach: enhancing design conversations in architecture education. PhD thesis, Victoria University, Wellington

Belluigi, D. Z. (2016) Constructions of roles in studio teaching and learning, International Journal of Art \& Design Education, Vol. 35, No. 1, pp. 21-35.

Dannels, D. P. (2005) Performing tribal rituals: a genre analysis of 'crits' in design studios, Communication Education, Vol. 54, No. 2, pp. $136-60$.

Demirbaş, O. O. (2001) The relation of learning styles and performance scores of the students in interior architecture education. PhD thesis, Bilkent University, Turkey

Demirbaş, O. O. \& Demirkan, H. (2003) Focus on architectural design process through learning styles, Design Studies, Vol. 24, No. 5, pp. 437-56.

Farivarsadri, G. (2001) A critical view of pedagogical dimensions of introductory design in architectural education, Architectural Education Exchange 2001, Architectural Educators: Responding to Change. Cardiff: Welsh School of Architecture, Cardiff University.

Fischer, G., Nakakoji, K., Ostwald, J., Stahl, G. \& Sumner, T. (1998) Embedding critics in design environments, in M. Maybury \& W. Wahlster [Eds] Readings in Intelligent User Interfaces. San Francisco, CA: Morgan Kaufman, pp. 537-61

Gray, D. (2001) A Briefing on Work-Based Learning. Bristol: Higher Education Funding Council for England (HEFCE)

Kent, L. A. (2001) The case of Lucio Pozzi: an artist/teacher's studio critique method. PhD thesis, Teachers College, Columbia, USA

Kim, M. J., Ju, S. R. \& Lee, L. (2015) A cross-cultural and interdisciplinary collaboration in a joint design studio, International Journal of Art \& Design Education, Vol. 34, No. 1, pp. 102-20.

Koch, A., Schwennsen, K., Dutton, T. A. \& Smith, D. (2002) The Redesign of Studio Culture: A Report of the Aias Studio Culture Task Force. Washington, DC: American Institute of Architecture Students

Ledewitz, S. (1985) Models of design in studio teaching, Journal of Architectural Education, Vol. 38, No. 2, pp. 2-8.

Maturana, B. C. (2014) Where is the 'problem' in design studio: purpose and significance of the design task, International Journal of Architectural Research: ArchNet-IJAR, Vol. 8, No. 3, pp. 32-44.

Motley, P. (2015) Learning - to and from - the visual critique process, New Directions for Teaching and Learning, No. 141, pp. 77-86

Nicol, D. \& Pilling, S. [Eds] (2005) Changing Architectural Education: Towards a New Professionalism. London: Taylor \& Francis

Oh, Y. (2010) Toward a theory of design critiquing - the furniture design critic program. PhD thesis, Carnegie Mellon University, USA (online). Available at: http://dl.acm.org/citation.cfm?id=2519875 (accessed 15 May 2015)

Oh, Y., Ishizaki, S., Gross, M. D. \& Do, E. Y. L. (2013) A theoretical framework of design critiquing in architecture studios, Design Studies, Vol. 34, No. 3, pp. 302-25.

Ostermann, A. C. (1998) Drawing on words and words on drawings: construction of identity and negotiation of expertise in design juries in the school of architecture. Paper presented at the American Association for Applied Linguistics Conference, Seattle, WA.

Sagun, A. (2003) Evolutionary collaborative design studios. PhD thesis, Bilkent University, Turkey.

Salama, A. (1995) New Trends in Architectural Education: Designing the Design Studio. Raleigh, NC: Tailored Text \& Unlimited Potential Publishing.

Schön, D. A. (1983) The Reflective Practitioner: How Professionals Think in Action. New York: Basic Books.

Schön, D. A. (1985) The Design Studio: An Exploration of its Traditions and Potentials. London: RIBA Publications.

Schunk, D. H. (1996) Learning Theories. Upper Saddle River, NJ: Prentice Hall.

Silverman, B. G. (1992) Survey of expert critiquing systems: practical and theoretical frontiers, Communications of the ACM, Vol. 35, No. 4, pp. 106-27.

Uluoğlu, B. (2000) Design knowledge communicated in studio critiques, Design Studies, Vol. 21, No. 1, pp. 33-58. 